\title{
A PUBLIC STATEMENT BY THE PRESIDENT OF THE METHODIST CHURCH IN FIJI
}

\author{
Reverend Tomasi Kanailagi
}

\section{Why a Public Statement?}

The Methodist Church (hereinafter referred to as 'the Church') issues the following public statement, with an objective to set the record straight in regards to the stand it has chosen to take during this time of national crisis.

The Church's MANDATE is scripturally based on the teaching that our Lord Jesus Christ came not only to seek but also to save the lost, including those who are in the hands of the Devil.

In addition, the Church, as the Body of Christ and as a corporate citizen, sees an urgent need to tell its Members (approximately 250,000 in all) and the Public at large why it has taken such a stand.

\section{How Many Sides Does the Church See?}

The Church sees essentially two Parties in the current national crisis, namely :

- IMG - Interim Military Government

- GSG - the George Speight Group

However, the Church understands that there are other various groups with varying vested interests, and who are also involved, either actively or passively, in the current showdown. 


\section{Is the Church Supporting the George Speight Group?}

NO, the Church IS NOT supporting the George Speight Group for the following reasons:

- The Church does not and cannot support any terrorist-type activity such as the holding of hostages for ransom at gunpoint at the parliamentary Complex.

- The Church, however, maintains contacts with the George Speight Group in matters relating to ongoing pastoral care and counselling.

- The Church has to be where its Members are to continue to be the Prophetic Voice even if it means being in the wilderness.

\section{Is the Church Praying for the George Speight Group?}

YES, the Church is praying for everyone, and during these times interceding especially on behalf of the George Speight Group, pleading before His Holy Presence to fill their lives with the love of God so that they may in turn truly love their captured hostages by setting them free to return to their homes to be with their loved ones.

Let me reiterate for the record that the Church's mandate is scripturally based on the teaching that our Lord Jesus Christ came not only to seek but also to save the lost, including those who are in the hands of the Devil.

As a matter of fact, a Delegation of the Standing Committee of the Church has on 2 June 2000 and 9 June 2000 visited Mr George Speight and his Group at the parliamentary complex, and has, among other things, pleaded with them to release the hostages at once, return all the arms and ammunition to the army, take up the Amnesty offer and join in the civil dialogue for the purpose of reshaping our united destiny.

\section{Which Side is the Church On?}

The Church is on the Interim Military Government side for the specific reasons expressed below. 
- The urgent need to restore law and order since the violent and destructive events of, and since, 19 May 2000.

- The sad and fatal shooting of the late Police Constable Filipo Seavula and the destruction of Fiji TV One Station by armed thugs and violent mobs during the night of 28 May 2000.

- The impending threat on the life of His Excellency the President and Tui Nayau during the night of, and since, 29 May 2000.

- The shooting by armed gunmen from behind human shield, resulting in serious injuries sustained by three army personnel lawfully engaged in manning police checkpoints on 29 May 2000.

- The inability of the unarmed Fiji Police Force to guarantee the safety and protection of life and property against the criminal activities of the armed mob.

- The unavoidable and unfortunate decision taken by His Excellency and Tui Nayau to hand over executive authority of the State to the Republic of Fiji Military Forces.

The Church invariably believes that the Republic of Fiji Military Forces is the only legitimate institution capable of restoring law and order under the prevailing circumstances.

With respect, Ratu Timoci Silatolu of the George Speight Group has, during TV One's Close-up Program on 11 June 2000, been honest to admit that they are not capable of controlling the recent spate of violence and the ongoing criminal activities by thugs and mobs based at the parliamentary complex, notwithstanding the George Speight Group's attempts to put a stop to such criminal activities.

Further, it is the considered view of the Church that the Republic of Fiji Military Forces, and not the George Speight Group, has passed one of the legal tests accepted by judicial courts of the Commonwealth, that is to say 'a competent and effective overthrow of the existing system of government' and thus paving the way to making another Constitution.

Lest we forget, this principle very well applied to the events of 1987 and the subsequent promulgation by Decree of the 1990 Constitution of Fiji. 
Indeed, the Church joins the Judiciary, the Public Service, the Police, the Business Sector and a wide cross-section of Fiji's Community, in lending its support to the Commander and Head of Government, Commodore J. Voreqe Bainimarama, MSD, JSSC, PSC.

\section{What Mandate Would the Church Grant the RFMF?}

The Church, as a corporate citizen, would, so to speak, entrust in the Interim Military Government the following mandate :

- To Restore Peace, Order and Good Government;

- To Protect Life and Property;

- To Restore Normalcy; and

- To Expedite a Quick Return to Democratic Rule for the People and by the People of Fiji.

\section{What is the Objective of the George Speight Group?}

As we understand it, the objectives sought by the George Speight Group are as follows :

- To abrogate the 1997 Constitution;

- To remove the President;

- To make a new Constitution that guarantees, inter alia, indigenous political rule; and

- $\quad$ To be granted Amnesty.

\section{Has the George Speight Group Achieved their Objectives?}

Yes, as we have seen and as we are assured as follows:

- The 1997 Constitution has been removed by the Interim Military Government;

- The President and Tui Nayau has effectively vacated Office; 
- The Commander and Head of the Interim Military Government has assured Amnesty to Mr George Speight and the perpetrators of the armed-civilian 'coup d'état'; and

- The Commander and Head of the Interim Military Government has assured the establishment of a Constitutional Review Committee to receive public submissions, including those from the George Speight Group.

\section{In What Way Can You Help?}

The Church believes that the real solution rests with you and me, for instance:

- If you are a Chief, please request your people, if they are inside the parliamentary complex, to return home.

- If you are a parent, either mum or dad, please request your child or children, if she or he is, or they are, inside the parliamentary complex, to return home.

- If you are a wife or husband, please request your spouse, if she or he is inside the parliamentary complex, to return home.

- If you are a Priest, Minister, Deaconess, Sister, Elder, Pastor or Preacher, please request your congregation members, if they are in the parliamentary complex, to return home.

- If you are a friend, please request your friend or friends, if she or he is, or they are, inside the parliamentary complex, to return home.

- If you are an Employer, please assist by maintaining your employment within your capacity and means.

- If you are an Employee, please assist by being faithful and loyal to your Employer.

- If you are a trade unionist, please assist by pleading with your overseas counterparts to lift trade bans against our Fiji. 
- If you are a responsible human being, you can help by showing love, and compassion to your fellow human beings who are in need of your immediate assistance, especially during these difficult times, irrespective of race, religion, denomination, colour or creed.

Thank You and May God Bless You All. 